HSTC Bulletin

Journal of the History of Canadian Science, Technology and Medecine

hstc

Revue d'histoire des sciences, des techniques et de la médecine au Canada

bulletin

\title{
The Canadian Genius: Biographical Sketches
}

\section{Donald J.C. Phillipson}

Volume 1, numéro 4 (4), august 1977

URI : https://id.erudit.org/iderudit/1083903ar

DOI : https://doi.org/10.7202/1083903ar

Aller au sommaire du numéro

Éditeur(s)

HSTC Publications

ISSN

0228-0086 (imprimé)

1918-7742 (numérique)

Découvrir la revue

Citer ce document

Phillipson, D. J. (1977). The Canadian Genius: Biographical Sketches. HSTC

Bulletin, 1(4), 4-4. https://doi.org/10.7202/1083903ar 
(University Toronto Archives), C.E.S. Franks (Queen's) and D. W. Thomson. Everyone with an interest in scientific and technical archives may attend. Further information can be obtained from Dr. Ticker at the NRC (Ottawa, Ontario. K1A OR6) or by phoning (613) 993-0286.

\section{The Canadian Genius: Biographical Sketches}

I have it in mind to prepare a book of biographical sketches of Canadian men of distinction in science: to be collected from other sources where possible (to save labour and to give wider distribution to those good memoirs that may already have been written specially for the occasion.

There are two central aims: to provide the general reader with an outline of science in Canadian history and Canadian contributions to world science; and to initiate the scholarly examination of what (if anything) may be characteristic of working Canadian scientists.

Some number between 12 and 24 individuals will eventually be presented. The draft list (classified roughly by type) includes:

Builders: Msgr. Alexandre Vachon (Laval chem. school) H.M. Tory (U. Alberta, ARC, NRC, Carleton) E.W.R. Steacie (McGill, NRC) Sir W. Macdonald (university endowments)

Solitaries: Michel Sarrazin (early biology)

Abbe Provancher ( 19 th century field biology)

D.W. Stedman (NRC chemist/inventor)

Gerhard Herzberg (Nobel)

Bureaucrats: Sir $W$. Dawson (or Sir $W$. Logan perhaps)

Sir C. Saunders (CDA)

C.J. Mackenzie (NRC)

A.G. Huntsman (FRB)

Main stream: Sir. F. Banting (Nobel)

J. B. Collip (Insulin and ACTH)

D.O. Hebb (McGill psychology)

W.B. Lewis (AECL)

Correspondence is invited on all aspects of this outline: choices of individuals, their classification, and the central theme (viz. whether there is or not anything characteristic of these men's contributions to either Canadian life or world science.)

Donald J.C. Phillipson

Hall's Road

Carlsbad Springs, Ontario

KOA IKO 